\title{
Protestant Social Ethics and Catholic Social Ethics: a dialogue towards just health
}

\author{
Ética Social Protestante e Ética Social Católica: \\ um diálago em vista da justiça na saúde
}

Alexandre Andrade Martins

\begin{abstract}
This article suggests a dialogue between Protestant Social Ethics and Catholic Social Ethics in the field of healthcare. It argues that these two traditions, besides their differences and particularities, can establish a fruitful dialogue in order to address the challenges in health care, especially those connected to justice in health. This paper does not focus on issues of clinical bioethics, but rather on issues of global health and health inequalities. It will approach Protestant Social Ethics and health issues in dialogue with Catholic Social Ethics, especially its liberating approach grounded on the preferential option for the poor. This paper is divided into three parts: first, it presents some general lines about Protestant Social Ethics developed in the USA and its particularities comparing it with Catholic Social Ethics. Second, it highlights some insights from Protestant Social Ethics that contribute to the ethical debate on justice in health. Third, it applies some aspects of Protestant Social Ethics and the preferential option for the poor in concerns of justice in health care.
\end{abstract}

Keywords: Protestant Ethics. Catholic Ethics. Health Inequalities. Poor. Justice. 


\section{Resumo}

Esse artigo sugere um possível diálogo entre a Ética Social Protestante e a Ética Social Católica na área da ética da saúde (ou bioética). Ele argumenta que essas duas tradições, apesar das suas diferenças e particularidades, podem estabelecer um diálogo produtivo com o objetivo de iluminar os desafios na área da saúde, especialmente os relacionados à questão da justiça na saúde. Esse trabalho não foca em questões de bioética clínica, mas nas problemáticas de saúde global e iniquidades na saúde. A artigo apresenta uma reflexão sobre a Ética Social Protestante em diálogo com a Ética Social Católica, especialmente sua vertente libertadora fundamentada na opção preferencial pelos pobres. Dessa forma, o texto está dividido em três partes: a primeira apresenta algumas linhas geral da Ética Social Protestante desenvolvida nos EUA e suas particularidades comparando-as com a Ética Social Católica. A segunda parte destaca alguns insights da Ética Social Protestante importantes para o debate ético sobre justiça na saúde. A terceira aplica esses aspectos destacados da Ética Social Protestante e a opção preferencial pelos pobres nas questões relacionadas à justiça no mundo da saúde.

Palavras-Chave: Ética Protestante. Ética Católica. Iniquidades na Saúde. Pobre. Justiça.

\section{Introduction}

Years ago, I was working at the emergency room of a public hospital in a poor area of a low-income country. This hospital was extremely full of sick people who needed healthcare assistance. Its physical conditions were precarious in addition to lack of staff and stuff. Healthcare professionals had to do some kind of miracle to serve those who were sick. I was working there as a nursing trainee in the emergency room. It was six hours day of working under high tension, screaming, tears, and patients spread everywhere, in beds, chairs, and on the floor. All health professionals did not mind about the religious beliefs of those people. They just wanted to care for them. But it was not easy!

This reality is the context of many healthcare environments spread throughout the world, which affect primarily low-income countries and prevent 
the poor from accessing healthcare services. The hospital where I worked did not have a problem in itself. It was a consequence of some structural problems based on social injustice. The drama of that hospital and its health professionals is an example of social, political, and economic options that dismiss an integral vision of human development in order to facilitate liberal market and economic transactions that make health care a commodity. As a result, those who cannot afford private healthcare assistance have no right to health care of quality or there is no assistance for them at all.

The hospital where I worked is part of a public healthcare system, but this system is still under the judgment of liberal economies that prioritize the "health market" in order to create profit and economic growth. This system does not work together with social development and rejects a conception that social goods must to be made available for all as primary needs to let people flourish. ${ }^{1}$ The market system promotes status quo, focuses on profit, and leads to accumulation of wealth in the hands of a few people. Consequently, it makes the poor poorer by keeping them unable to access social goods that they need to flourish. Among these goods, there is health/health care.

This system is violent and cruel with those who are at the bottom of society. Liberation theologians named it institutionalized violence, responsible for preventing the poor from accessing social goods. ${ }^{2}$ In health care, from a medical-anthropological perspective, Paul Farmer calls this system of structural violence, a violence structured politically and economically that creates victims, the poor, and makes them suffer and die early because of lack of essential goods to survive. ${ }^{3}$ Theologically, some Christian traditions have called that social $\sin .^{4}$

This context of structural violence in health care is a challenge to Christian ethics. Does theology have something to say about structural violence and justice in health care? Do Protestant Social Ethics and Catholic Social Ethics have sources to address issues of justice and inequalities in health care? These questions are the motivation behind this paper that will draft a dialogue

\footnotetext{
${ }^{1}$ Cf. SEN, A. Development as freedom. New York: Anchor Books, 2000, pp. 4-11.

${ }^{2}$ See, for example, GUTIERREZ, G. Teologia da libertação. 4. ed. Petrópolis, RJ: Vozes, 1983, p. 42.

${ }^{3}$ FARMER, P. Pathologies of power: health, human rights, and the new war on the poor. Berkeley: University of California Press, 2003, pp. 40-41.

${ }^{4}$ See, for example, John Paul II's encyclical Sollicitudo Rei Socialis (1987), no. 36. Retrieved from: $<$ http://w2.vatican.va/content/john-paul-ii/en/encyclicals/documents/hf_jp-ii_enc_3012 1987_sollicitudo-rei-socialis.html>. 27 / January / 2017.
} 
between Protestant Social Ethics (PSE) and Catholic Social Ethics (CSE) in the field of healthcare ethics.

I will argue that these two traditions, besides their differences and particularities, can establish a fruitful dialogue in order to address challenges in health care, especially as they are connected to justice. I will not talk about health care in general; my preoccupation is those health issues that come from the connection between structural violence, poverty, and diseases. ${ }^{5}$ In other words, this paper will not focus on issues of clinical bioethics, but rather on issues of global health and health inequalities. I will approach PSE and health in dialogue with CSE and its liberating aspect grounded on the preferential option for the poor. This approach considers the experience of the poor, ${ }^{6}$ their reality, their suffering, and their hope for liberation as a hermeneutical leans to see theological social ethics and social issues, such as health inequalities. This paper will be divided into three parts: First, I will present some general lines about PSE and its particularities comparing it with CSE. Second, I will highlight some insights from PSE that contribute to the healthcare ethics debate and address issues on justice in health. Third, it will be an application of some aspects of PSE and the preferential option for the poor on concerns of just health.

\section{Protestant Social Ethics and Catholic Social Ethics}

Many theologians like to make a distinction between Protestant and Roman Catholic ethics (that I will call here only by 'Catholic') by the terms Christian Ethics for Protestants, and Moral Theology for Catholics. D. Stephen Long is one who defends this distinction and nomenclature by saying they

${ }_{5}^{5}$ For a study that shows the connection between poverty and diseases, see: Global Burden Disease Study 2015 - Sustainable Development Goals Collaborators. "Measuring the health-related Sustainable Development Goals in 188 countries: a baseline analysis from the Global Burden of Disease Study 2015". The Lancet 338 (September 2016), pp. 1813-1850. Retrieved from: <http://dx.doi.org/10.1016/S0140-6736(16)31467-2>. 31 / December / 2016.

${ }^{6}$ I use the term experience of the poor in a correlation to James Cone's concept of black experience. For him, black experience is the experience of suffering of the black community under white supremacy. This experience generates an identification with Jesus' cross, a specific social-cultural background, and a way of resistance. See: CONE, James C. The cross and the lynching tree. Maryknoll, NY: Orbis Books, 2013, pp. 2-3. The experience of the poor shapes the worldview and faith of the poor. This generates a historical praxis and a liberation ethics of resistance, struggle, and hope. 
"represent different approaches to the Christian moral life". In addition, he affirms: "The main difference between them is that moral theology recognizes Christian dogma as essential to the moral life, while Christian ethics either tempers or overcomes it for the sake of the moral life". ${ }^{8}$ Historically and as academic disciplines, this division and main difference between them seem to fit well and to be appropriated. Moral theology appeared as a discipline after the Council of Trent had created seminaries for the education of priests. After Trent, the Catholic Church organized theological disciplines following Saint Thomas Aquinas in which the moral life of Christians comes after the reflection on the mystery of God, although one can affirm that the origin of moral theology in the Catholic Church leads us to the time of confessionals that worked as penitential manuals to guide the Christian life. ${ }^{9}$ Manuals of moral theology were adopted by Trent and had been presented in the Catholic Church until Vatican II when a new time started for moral theology. ${ }^{10}$

Christian ethics is a modern phenomena and, according to Long, its "primary audience will be more modern social formations such as the nationstate, corporations, global market or the university. It tends to focus on policy implications that persons in charge of those institutions could use irrespective of any person's faith or lack thereof". ${ }^{11}$ Christian ethics also appears as a discipline in Protestant seminaries in the US at the end of $19^{\text {th }}$ century. Gary Dorrien affirms that Christian ethics is "a tradition that began with the distinctly modern idea that Christianity has a social-ethical mission to transform the structures of society in the direction of social justice". ${ }^{12}$ It assumed the

\footnotetext{
${ }^{7}$ LONG, D. S. "Moral theology". In: WEBSTER, John (Org.). Oxford handbook of systematic theology. Oxford, NY: Oxford University Press, 2006, p. 457.

${ }^{8}$ LONG, "Mora Theology", p. 457.

${ }^{9}$ Cf. KEENAN, J. F. A history of catholic moral theology in the twentieth century: from confessing sins to liberating consciences. New York: Continuum, 2010, pp. 2-3.

${ }_{10}$ According to Marciano Vidal, Vatican II provided a new orientation for the Christian community's moral interpretation and commitment. One of the most important elements of this new orientation is the moral consciousness, stated in Vatican II' document Gaudium et Spes, no. 16. Cf. VIDAL, Marciano. "Gaudium et spes y teología moral: A los 50 anos del Concilio Vaticano II". Moralia 35 (2012), pp. 122-130. On this new time for moral theology in the Catholic Church, see also: KEENAN, J. F. A history of catholic moral theology in the twentieth century: from confessing sins to liberating consciences. New York: Continuum, 2010, pp. 95-98. ${ }^{11}$ LONG, "Moral Theology", p. 458. On the other hand, Long says that moral theology has a different audience that is primary the Church herself.

${ }^{12}$ DORRIEN, G. Social ethics in the making: interpreting an American tradition. Chichester, UK / Malden, MA: Wiley-Blackwell, 2011, p. 3.
} 
Liberal Protestantism and its social ethics and politics in the midst of North American Society. Hence, one can say that European Liberal theologians are the 'fathers' of Christian ethics in the US, especially at its beginning as a discipline in social ethics. Dorrien suggests that: "The three towering figures in American Christian social ethics are Walter Rauschenbusch, the prophet of the social gospel; Reinhold Niebuhr, the theorist of Christian realism; and Martin Luther King, Jr, the leader of modern America's greatest liberation movement". ${ }^{13}$ Dorrien stresses that three movements shape the origin and first development of Christian ethics, namely, Social Gospel, Realism, and Liberation Theologies.

Long's distinction, moral theology and Christian ethics, is not exhaustive. On the one hand, his presentation of Christian ethics seems appropriate and reflects Dorrien's description. Both agree about the meaning of Christian ethics in the US, its modern social foundation and political concerns, and its development in the midst of the North American Protestantism in the $20^{\text {th }}$ and $21^{\text {st }}$ centuries. On the other hand, Long's account of moral theology seems very narrow and does not appear to consider the raise of Catholic Social thought from papal social encyclicals, which began with Leo XIII in 1891, nor the theological ethical reflection after Vatican II. He is right when he affirms that Catholic moral theology flows from Catholic doctrine (but this doctrine does not only include dogmas, but it is also Scripture, Magisterium, and Tradition that are always sources of new ethical reflections and make it to be dynamic in interaction with history). However, CSE is also challenged to address social and political issues of history paying attention to the signs of the times. ${ }^{14} \mathrm{CSE}$ is not only a teaching for Catholic audiences, but it addresses society as a whole and invites all humanity to work for building a world grounded on justice, solidarity, and peace. It is not by chance that social encyclicals are addressed to "the Bishop, Priest, Religious, the Faithful, and All Men of Good Will". ${ }^{15}$ In this sense, there is much more in common between moral theology and Christian ethics in the $20^{\text {th }}$ and $21^{\text {st }}$ centuries that

\footnotetext{
${ }^{13}$ DORRIEN, Social ethics in the making, p. 3.

${ }^{14}$ Gaudium et Spes (1965), no. 04. Retrieved from: <http://www.vatican.va/archive/hist_councils/ii_vatican_council/documents/vat-ii_const_19651207_gaudium-et-spes_en.html>. 27 / January / $201 \overline{7}$.

${ }^{15}$ See the collection of social encyclical in O'BRIEN D. J.; SHANNON, T. A. (Orgs.). Catholic social thought: the documentary heritage. Maryknoll, NY: Orbis Books, 2010.
} 
Long describes. Therefore, this differentiation does not reflect properly Protestant and Catholic traditions in social ethics.

In another work, Long himself seems not to support this distinction Christian ethics and moral theology for Protestants and Catholics. He says: "Christian ethics emerges out of the shared Jewish and Christian mission to make God's name holy throughout creation by building a city or house. This requires a twofold approach to ethics, which can best be characterized by the call to Abraham: 'do not be like the other nations... for the sake of the nations"". ${ }^{16}$ In this essay, Long uses the call of Abraham to present the twofold approach to ethics by Christianity. One is what makes Christian life different from other ways of life or traditions. It is what is proper in Christian ethics that requires 'habituation' and 'infusion', that is, assuming the life of Christ and infusion of God's grace that communicates the Holy Spirit in attention to liturgical life. ${ }^{17}$ Another is the relation with the world that proceeds from Christian identity and life. He says: "Christian Ethics serves the nation by reminding government of its limits, but it also makes important positive contributions. It should affirm what is good in every culture, working in cooperation with it". ${ }^{18}$ Protestant and Catholic ethics are at the same point of shaping their identity and moral life grounded on habituation to Jesus' life and teaching. They act in the world in a positive (and prophetic) relationship with all societies and their social, political, and economic structures and institutions. In addition, both Protestants and Catholics are also in relationship among themselves. One can affirm they have the ethical responsibility to contribute for building justice and peace in the world from their Christian identity (even considering particularities among Protestants and Catholics), as a community of Jesus' disciples, and through social and political participation.

Stanley Hauerwas stresses that there is no generic ethic. All ethics must have an adjective. So ethics must be Christian, Buddhist, Kantian, secular, and so forth. ${ }^{19}$ However, it is not clear in his thought how different ethics are in relationship to a "fragmented and violent world" or in a pluralistic society in which different ethics have to live side by side in the same social and political

\footnotetext{
${ }^{16}$ LONG, D. S. Christian ethics: a very short introduction. New York: Oxford University Press, 2010 , p. 51.

${ }^{17}$ LONG, Christian ethics, p. 51.

${ }^{18}$ LONG, Christian ethics, p. 77.

${ }^{19}$ HAUERWAS, S. The peaceable kingdom: a primer in Christian ethics. Notre Dame: University of Notre Dame Press, 1991, pp. 1-2.
} 
arena. He says ethics responds to particular challenges of our context and historic situation. ${ }^{20}$ And Christian ethics addresses these challenges from its convictions present in a community that embodies Jesus' life and teaching. ${ }^{21}$ From the community, Christian ethics engages in a dynamic dialogue with the world, that is, social, political and economic structures and institutions present in all societies, in order to promote justice and peace.

Christian ethics includes Protestant Social Ethics and Catholic Social Ethics that are united by the same foundation, Jesus Christ. They participate in the same socio-political arena, and have the same goal: justice and peace. They have an identity as Christian communities, which engage in social life from their faith in Jesus. Based on this principle, in a democratic society, PSE and CSE have legitimacy and responsibility to participate in the public debate on justice in health care. Moreover, both traditions have elements that offer contributions to promote population health in the world.

\section{Some Insights From Protestant Social Ethics To Just Health Debate}

I must begin this section addressing three challenges. The first challenge in seeking some insights from PSE to justice in health care is to delimit PSE. While this task in CSE is not difficult because it flows basically from Catholic social teaching concentrated in the social encyclicals and other magisterial documents, PSE does not have a common magisterium. Protestantism represents a body of a variety of Christian traditions. Here I do not want to seek for any definition of Protestantism. But I want to present PSE as having a tradition among Protestantism that deals with social ethics. However, this must be narrowed to make sure which tradition I am presenting here.

First of all, I refer to PSE as a tradition on social ethics that began in the U.S. with the Social Gospel. So I adopt Gary Dorrien's delimitation of Christian social ethics and its origin and development in the USA. ${ }^{22}$ Nevertheless, this delimitation is not sufficient because it is still broad. From the beginning of the Christian social ethics with the Social Gospel movement, the number of Protestant social ethicists is almost uncountable. This requires choosing

\footnotetext{
${ }^{20}$ Ibid., p. 2.

${ }^{21}$ Ibid., p. 16.

22 DORRIEN, G. Social ethics in the making: interpreting an American tradition. Chichester, UK / Malden, MA: Wiley-Blackwell, 2011, pp. 6-10.
} 
some names that can represent this tradition. Following Dorrien, I chose one representative of the three major movements of PSE: Walter Rauschenbusch (Social Gospel), Reinhold Niebuhr (Realism), James Cone (Black Liberation Theology). In addition, I will present other names in the some tradition, such as John H. Yoder and Stanley Hauerwas.

The second challenge is the presence of theological ethics in public debate on justice in health care. Some affirm that theological ethics is only for the internal life of Christian communities. Protestant ethics may be understood as an ecclesiology, that is, an ethical reflection on the moral life of Christian communities. Without a careful reading, authors such as Yoder and Hauerwas can be interpreted as ecclesiologists who talk about morality for their local Christian communities because they typically emphasize the crucial role of Christian community to embody the life and teaching of Jesus. In part, this interpretation is not wrong. They do emphasize the Christian community, but they do not close this community in a ghetto isolated from society. The Christian community is a witness of a new social organization, which shows necessary values to the whole humanity to build a society of reconciliation, justice, and peace. This community (or communities) is part of the political arena and has a social role. This legitimates the Christian communities participation in the political debate because it is part of the socio-political reality. Therefore, Protestant ethics cannot be narrowed to an ecclesiology. Moreover, theological ethics must claim its space to participate in the public debate on justice in health.

Lisa S. Cahill (who by affiliation and faith is a Catholic theologian in deep dialogue with PSE and has as one of her main sources the Protestant theologian James Gustafson) affirms that theological bioethics has an important social role and theologians have the right to participate in the public debate. Grounded on sources, such as biblical images, moral values, and systematic concepts, the task of theology is to shed light on the life of the religious community and socio-political organization as well. In sociopolitical life, Cahill stresses that theologians must have prophetic voices and enter into public debate. Hence, theological bioethics must have a voice in bioethical and medical ethics debates. ${ }^{23}$

Cahill argues for a participatory democracy in which religious traditions have the right to be part of the public debate. Therefore, she proposes a

${ }^{23}$ Cf. CAHILL, L. S. Theological bioethics: participation, justice and change. Washington, D.C. Georgetown University Press, 2005, pp. 17-19. 
"participatory theological bioethics" by saying: "Participatory theological bioethics operates simultaneously in many spheres of discourse and activity, from which it is possible to affect the social relationships and institutions that govern health care". ${ }^{24}$ Then, she proposes five modes of discourse in which theological bioethics must engage: ethical, policy, prophetic, narrative, and participatory. ${ }^{25}$ These discourses are dynamic and are in interaction among themselves.

Theological bioethics has held an important influence in bioethical issues. It has participated in decision-making processes in health, especially in the context of religious pluralism and freedom. Religious values and beliefs impact many healthcare decisions and, sometimes, create ethical dilemmas. This requires some theological knowledge in order to make the best decisions. Cahill argues that the social role of religious traditions legitimates participation of theological bioethics, through theologians from different traditions, in the public forum. ${ }^{26}$

The reflections and studies made in the field of theological bioethics also offer a contribution that goes beyond clinical bioethics because of its role in the social arena as advocate for the poor and vulnerable. This is part of Cahill's argument that supports the preferential option for the poor and prophetic voices as part of theological discourse in the public arena. This option leads to a broad dialogue committed to engage the poor in the just health debate. Therefore, Cahill does not only stress the importance of theological bioethics in the public debate, but also a participatory theological bioethics with practices that embody the participation of the poor with their experiences and narratives. ${ }^{27}$

The third challenge is to seek for some insights from Protestant authors who can contribute to the health care ethics debate on justice. This task is not easy either and it is probably a subject for a doctoral dissertation and not for a paper. However, I will initiate this work. By a modest presentation of some insights from the theologians I have named before, I believe they can shed light on justice in health care. It is necessary to clarify that these selected scholars deal with social and political ethics from a Protestant perspective, but none of them have reflected on health care ethics, especially regarding the

\footnotetext{
${ }^{24}$ Ibid., p. 24.

${ }^{25}$ Ibid., pp. 35-36.

${ }^{26}$ Ibid., pp. 25-26.

${ }^{27}$ Ibid., pp. 11-12.
} 
link between structural violence, poverty, and population health. Hauerwas is the only one who has several essays on bioethics, but he focuses on issues of clinical bioethics, such as abortion, birth control, and euthanasia. ${ }^{28}$ All of these Protestant theologians look at society and its social, political, and economic issues as a whole, without addressing specific topics, such as public health care. They look at society from their own Christian traditions (different Protestant denominations) and in dialogue with other theologians from PSE and theologians from the Protestant tradition in general, especially classical theologians such as Martin Luther and Liberal Protestants.

As the title of this paper expresses, I will look at these authors in a dialogical perspective with the Catholic tradition. But what does this mean? It means, first of all, that, as a Catholic theologian, I am naturally influenced by my Catholic background. Second, Catholic social teaching has social principles that are clearly defined and very often the mission of Catholic moral theologians is to reflect how these principles can be applied in different social contexts in order to answer historical challenges and to lead society to justice, peace, and the empowerment of the poor. Therefore, my task is to identify some insights from PSE that can be methodologically useful in the same way as Catholic social principles and, ergo, contribute to the just health debate. Now, I will suggest a draft of these PSE insights. (I chose not to refer to them as principles because they are more dynamic ideas than static concepts that could be presented as principles. Methodologically, insights reflect the diversity of PSE that, by nature, does not support this kind of affirmation of the Protestant social principles). Moreover, the last part of this essay will correlate these insights with some Catholic social principles in health care from the perspective of the poor.

After addressing these three challenges: delimitation of PSE, the legitimization of theological ethics in the public debate in health care, and seeking for PSE insights for justice in health, I will now draft the insights from authors I selected in which I will present only some ideas and dismiss biographical introduction.

I begin with Walter Rauschenbusch who was an important figure of the

\footnotetext{
${ }^{28}$ See: HAUERWAS, S. "God, Medicine, and the Problems of Evil". Reformed Journal 38 (1988), pp. 16-22. HAUERWAS, S. "Abortion and narrative ethics: A critical appraisal of Callahan and Grisez”. Cross Currents 21 (1971), pp. 399-414. HAUERWAS, S.; BONDI, R. "Memory, community and the reasons for living: theological and ethical reflections on suicide and euthanasia". Journal of the American Academy of Religion 44 (1976), pp. 439-452.
} 
Social Gospel movement. Rauschenbusch affirms that there is a Social Gospel and it requires a theology that can ground it. ${ }^{29}$ His effort is to develop this theology. ${ }^{30}$ He says: "Social Gospel is less concerned about the metaphysical problems of God and more about a progressive social incarnation of God". ${ }^{31}$ This consciousness of a social incarnation of the presence of God happens through the social action of Christian community in which faith means prophetic vision. ${ }^{32}$ At the center of this consciousness is the doctrine of the kingdom of God that is the Social Gospel..$^{33}$

From the perspective of the kingdom of God and a prophetic vision, Rauschenbusch develops a reflection on collective sin and its transmission. He says that there is a personal sin and a personal transmission of original sin. Moreover, there is a collective transmission of sin that perpetuates original sin through social practices, institutions, and traditions responsible for socializing vices and crimes. ${ }^{34}$ This is a super-personal force and power upon the community. Then he stresses: "The social gospel realizes the importance and power of the super-personal forces in the community. It has succeeded in awakening the social conscience of the nation to the danger of allowing such forces to become parasitic and oppressive". ${ }^{35}$ In other words, the social gospel has the task of awakening the community to social forces that lead to oppression as well as opening the community to a sense of solidarity.

Rauschenbusch highlights solidarity as one instrument against the force of collective sin. He says: "The sense of solidarity is one of the distinctive marks of the true followers of Jesus". ${ }^{36} \mathrm{He}$ connects it to the prophetic experience that is "social, political, and solidaristic". ${ }^{37}$

${ }^{29}$ RAUSCHENBUSCH, W. A theology for the social gospel. Louisville, KY: Westminster John-Knox Press, 1997, pp. 08-09.

${ }^{30}$ This is the project of this book $A$ theology for the social gospel, in which he reflects classical theological themes, such as creation, sin, and incarnation, as a social engagement to transform the world.

${ }^{31}$ RAUSCHENBUSCH, A theology for the social gospel, p. 148.

${ }^{32}$ Ibid., p. 102.

${ }^{33}$ Ibid., p. 131.

${ }^{34}$ Ibid., p. 60.

${ }^{35}$ Ibid., p. 75.

${ }^{36}$ Ibid., p. 109.

${ }^{37}$ Ibid., p. 107. 
The kingdom of God is a historical force ${ }^{38}$ presented by Jesus. It shapes the Christian conception of freedom, justice, and solidarity. "The consciousness of solidarity, therefore, is of the essence of religion" and, together with freedom and justice, "are among the aims of the social gospel". ${ }^{39}$ Based on these values and in a prophetic vision, the social gospel leads the Christian community to an action of social transformation that can break the structure of collective transmission of sin. Rauschenbusch's insights open to a reflection in which solidarity is necessary to break structural violence that makes the poor victims of a system that prevents them from accessing health care.

Reinhold Niebuhr is a critic of the social gospel's optimism, despite the fact he supports a prophetic vision that "leads religion to emancipate itself from the fate". ${ }^{40}$ Niebuhr has a pessimist vision of historic realization of the kingdom of God preached by Jesus and his ethics of love. He is realistic in rejecting pacifism, idealism, and perfectionism. However, he relates love with justice that is at the center of Christian ethics. ${ }^{41} \mathrm{He}$ stresses connection between equality, justice, and love. He says: "Equality is always the regulative principle of justice, and in the ideal of equality there is an echo of the law of love". ${ }^{42} \mathrm{He}$ presents equality as a rational and political ideal of the law of love, but equality cannot go beyond the political reality by itself. Moreover, equality cannot cover all stands of justice. "The principle of equality does not exhaust the possibility of the moral ideal involved in even the most minimal standards of justice. Imaginative justice leads beyond equality to a consideration of the special needs of the life of the other". ${ }^{43}$ To consider the needs of the others, love is necessary. Hence, the command of 'love your neighbor' becomes a defense against the egocentrism of a "cultural super-ego" that does not recognize others and their needs. ${ }^{44}$

The ideal of love and the principle of justice have a dynamic relationship in which "the law of love is not only in position of ultimate transcendence over all moral achievements, but that it suggests possibilities which immediately

\footnotetext{
${ }^{38}$ Ibid., p. 165.

${ }^{39}$ Ibid., pp.186-187.

${ }^{40}$ NIEBUHR, R. An interpretation of Christian ethics. Louisville, KY: Westminster John-Knox Press, 2013, p. 30.

${ }^{41}$ NIEBUHR, An interpretation of Christian ethics, p. 31.

42 Ibid., p. 108.

${ }^{43}$ Ibid., p. 109.

${ }^{44}$ Ibid., p. 116.
} 
transcend any achievements of justice by which society has integrated its life" ${ }^{45}$ Love is a virtue that is necessary for the realization of justice that goes beyond an instrumental justice based on equality. Niebuhr affirms that any system of justice is not perfect enough to "dispense with the refinements which voluntary and uncoerced human kindness and tenderness between individuals add to it". ${ }^{46}$ Moreover, the refinement of justice happens by the love of individuals. In other words, there is not political justice without social coercion that dispenses the law of love, a necessary virtue among individuals.

Niebuhr himself and some of his interpreters are pessimistic about whether this dynamic relationship between justice and love is possible in society. For that, Niebuhr affirms a necessary "transvaluation of values" as a result of Christian confrontation of reality. Nevertheless, when he says that love your neighbor as a law that refines justice because it leads people to see the needs of each other, I see here a strong insight for justice in health care that correlates with a conception that health care is a social good necessary to human flourishing. Health/health care is a human need that must be addressed for human development. Justice in health care cannot be based on a narrow conception that justice is to create possibilities for people to negotiate which kind of insurance they want to buy. This right - as a possibility, supposedly achieved by accessing opportunities - does not exist for the poor. Hence, health care is not a human right, but rather a commodity in which negotiation becomes a 'human right' that only the rich can fulfill. The law of love leads to seeing others and their needs. Consequently, justice and equality happen when these needs are met.

According to James Cone, the founder of Black liberation theology, Niebuhr's radicalism is timid and distant to the reality of those who are suffering. Cone talks from the U.S. context of racism and oppression of black people. To Niebuhr, the cross is at the center of Christian faith and its confrontation with reality leads to a "transvaluation of values". ${ }^{47}$ However, Niebuhr did not touch the concrete presence of Jesus' cross in U.S. society, "the black experience." Cone affirms: "Christian realism was not the only source of Niebuhr's radicalism, but also of his conservatism". ${ }^{48}$ Niebuhr did not make any effort to dialogue with black people and listen to them. In

\footnotetext{
${ }^{45}$ Ibid., p. 144.

${ }^{46}$ Ibid., p. 201.

${ }^{47}$ CONE, J. The cross and the lynching tree. Maryknoll, NY: Orbis Books, 2011, pp. 33-34.

${ }^{48}$ Ibid., p. 48.
} 
the end, Niebuhr's realism and theology of the cross remain at the level of theological abstractions. ${ }^{49}$

Cone's criticism of Niebuhr's realism leads us to the experience of those who are at the bottom of society where they are victims of oppression, exclusion, and violence. Cone talks about the 'black experience' and their identification with Jesus' cross. In the book The Cross and The Lynching Tree, Cone's social ethics presents the black struggle for social justice and freedom from their reality and religious experience. It is a Protestant Social Ethics that emerges from a social experience of the suffering of an entire community throughout its history marked by exploitation, oppression, marginalization, and death. In other words, it is the history of people who have been crucified by white supremacy and power. It is social prophetic ethics engaged in the black struggle for liberation. It is a theology of social commitment to change structures of racial injustice. Cone shows this in several ways, but I highlight his engagement with some black witnesses of this struggle for liberation: Ida B. Wells, Martin Luther King Jr., and Fannie Lou Hamer. All of them had the courage to risk their lives, defined by their faith and the cross of the black religious experience that shaped a black cultural resistance to white supremacy and their struggle for liberation. Some, like King, had the analogy of Jesus' cross and the lynching tree as the symbol of black people's cross as a theological reflection of the black religious experience. Others did not have this theological reflection, but they had the religious experience and knew that the lynching tree showed that "white Christianity was fraudulent" and opposed to true faith in Christ. ${ }^{50}$ The cross gives black people the courage to continue fighting for liberation, justice, and social transformation.

Cone's theology has a liberation approach to social reality from the experience of those who are oppressed, a concrete people with faces and names. This approach is similar to liberation theology's approach in the Catholic tradition that unites the poor in order to empower them, to give them voice, and to make them agents of their history. In just health, this leads to a people-centered framework that does not impose anything upon the poor, but join them in a dialogical perspective. This

\footnotetext{
${ }^{49}$ Ibid., p. 63.

${ }^{50}$ Ibid., p. 132.
} 
framework respects cultural diversity and local particularities, listens to the poor, and empowers them to participate in the decision-making process in health care. ${ }^{51}$

The last two Protestant theologians I briefly want to mention here are John H. Yoder and Stanley Hauerwas. Both thinkers emphasize the role of Christian communities in the political and social arena as witnesses of peace and justice from their own Christian identity and experience of a communal and liturgical life. Witness is the key category to understand the role of Christian communities in society. The community witnesses a new social organization grounded on Jesus' life and teaching. Both theologians are very Christocentric in presenting the "way of Jesus", according to Yoder's language, or "Christian convictions", in Hauerwas' terms. They lead to a "creative transformation" 52 in which Christian communities "consist in being a herald of liberation and not a community of slavery". 53 Hauerwas writes that the Christian community has a responsibility in the world to ensure social justice. And the first social task of the Church is to be a "servant community". 54

I end this section with Yoder and Hauerwas because they encourage Christian communities to establish dialogical relationships with society in ways that the church witness has power to touch social structures and to move them to social transformation. In health care, this witness grounded in a Christocentric perspective leads to putting those who are sick and poor at the center of church witness of social responsibility and creative transformation. Christians are invited to engage in the world of the sick and the poor to care for and empower them to be agents of social transformation.

\section{Protestant Social Ethics and Preferential Option for the Poor in Just Health}

This is my conclusive section in which I will point out the relationship between PSE insights for justice in health care and the preferential

\footnotetext{
${ }^{51}$ On the people-centered approach in health care, see: BIEHL, J.; PETRYNA, A (Orgs.). When people come first: critical studies in global health. Princeton: Princeton University Press, 2013. ${ }^{52}$ YODER, J. H. The politics of Jesus. Grand Rapids: Eerdmans, 1991, p. 185.

${ }^{53}$ Ibid., p. 148.

${ }^{54}$ HAUERWAS, The peaceable kingdom, p. 99.
} 
option for the poor as a Catholic social principle that arose in Latin America ${ }^{55}$ and was assumed by Catholic social teaching. ${ }^{56}$

The preferential option for the poor leads to a shift of perspective in health care from a top down way of seeing justice in health to a perspective from below in which the poor participate in the healthcare debate. Paraphrasing James Cone's concept of black experience, ${ }^{57}$ the 'poor experience' becomes relevant for just health. This also affects the perspective of seeing Catholic social principles, such as solidarity, subsidiarity, justice, and the common good. ${ }^{58}$ The preferential option for the poor also affects the way to see PSE insights that I index as: collective sin, solidarity, justice and the law of love, the experience of the oppressed, and the witness of the Church for creative transformation.

Paul Farmer uses the motto "the preferential option for the poor in health" to inspire and ground his "pragmatic solidary" in medicine. ${ }^{59}$ Catholic social principles, such as the common good and social justice that are also present in PSE insights, function as guideline to socio-political actions to address health inequalities. When the Catholic social teaching incorporates the preferential option for the poor, it opens to the participation of the poor as agents of social transformation and to a new perspective to address social issues that considers

\footnotetext{
${ }^{55}$ The preferential option for the poor is at the heart of liberation theology since its origin. It was formalized by the Latin American Bishops Conference of Puebla in 1979. Cf. Puebla, no. 1134. In: CONFERÊNCIA EPISCOPAL LATINO AMERICANA. Documentos dos Celam: Rio de Janeiro, Medellín, Puebla e Santo Domingo. São Paulo: Paulus, 2005.

${ }^{56}$ Pope John Paul II was the first pope to assume the preferential option for the poor as a Catholic Social principle. Cf. Sollicitudo Rei Socialis (1987), no. 36. Retrieved from: <http://w2.vatican. va/content/john-paul-ii/en/encyclicals/documents/hf_jp-ii_enc_30121987_sollicitudo-reisocialis.html>. 27 / January / 2017. Pope Francis, following the document of Aparecida, also highlights the preferential option for the poor as a Christological concept. Cf. FRANCIS, Pope. “Apostolic Exhortation Evangelii Gaudium" (2013), no. 198. Retrieved from: <http://www. vatican.va/holy_father/francesco/apost_exhortations/documents/papa-francesco_esortazioneap_20131124_evangelii-gaudium_en.html>. 31 / December / 2016.

${ }^{57}$ Catholic theologian Bryan N. Massingale continues Cone's theology of black experience by applying it in the context of Catholic Church in the U.S. and its struggle to assume an antiracism agenda that is, according to him, indispensable for social justice in the U.S. See: MASSINGALE, Bryan N. Racial justice and the Catholic Church. Maryknoll, NY: Orbis Books, 2010 .

${ }^{58}$ For a brief and concise presentation of Catholic Social principle, see: PONTIFICAL COUNCIL FOR JUSTICE AND PEACE. Compendium of the social doctrine of the church. Washington, D.C.: Libreria Editrice Vaticana, 2004, nos. 160- 208.

${ }^{59}$ Cf. FARMER, Pathologies of power, p. 138.
} 
the experience of the poor. In a few words, the preferential option for the poor together with Catholic social principles and PSE insights challenge us to a new social organization committed to fight against structural violence, responsible for victimizing the poor. They present a social vision in which all have the right to access what is necessary to meet human flourishing. Health care, as a social good ${ }^{60}$ belongs to the common good that must be shared by all. Justice in health care requires that all must have access to this social good in order to flourish and to promote population health. In addition, the common good presents that justice in health care does not happen isolated from other social goods and social justice as well. Therefore, the principle of the common good leads to actions that address the social determinants of health in order to promote population health.

The preferential option for the poor adds something extremely important and it re-orients the locus of just health debate. The connection between poverty and diseases is well known. Farmer says "diseases make an option for the poor". ${ }^{61}$ The option for the poor challenges actions and policies in social justice and health that begin from below, that is, from those who are suffering because of the burden of structural violence. Consequently, an approach from below orients the just health debate to the reality of where the poor are. As a practical and dynamic principle, the option for the poor calls our attention to the need of empowering the poor to be social agents in a way that they are able to access health care and participate in the common good.

There is no justice in health care if there is no adequate level of population health in which all are able to enjoy good health and restore it when they get sick. Moreover, there is no justice in health if there is no participatory social justice. ${ }^{62}$ Catholic Social Ethics and Protestant Social Ethics present principles and insights that encourage, first of all, a Christian commitment to social justice and solidarity, and actions that address social injustice and health inequalities. The preferential option for the poor shows the face of those who

\footnotetext{
${ }^{60}$ For a study of health care as a social good, see: CRAIG, D. M. Health Care as a social good: religious values and American democracy. Washington, D.C.: Georgetown University Press, 2014 (especially Chapter 3).

${ }^{61}$ FARMER, P. "Reimagining accompaniment: a doctor's tribute to Gustavo Gutiérrez". In: GRIFFIN, M.; BLOCK, J. W. (Orgs.). In the company of the poor: conversations with Dr. Paul Farmer and Fr. Gustavo Gutiérrez. Maryknoll, NY: Orbis Books, 2013, p. 22.

${ }^{62}$ For a good study about the relationship between social justice and health care, and why healthcare is a special good to create opportunities, see: DANIEL, N. Just Health: meeting health needs fairly. New York: Cambridge University Press, 2008.
} 
are suffering and guides political and social actions to promote population health from their perspective, experience of victims of structural violence, and struggle for liberation. The option for the poor lead us to join realities, such the one presented in the first page of this essay, and to listen to the voices of those who are there suffering, opened to learn from them.

\section{Conclusion}

I began this paper by presenting a sad reality of injustice and inequality in health care. That hospital is an example of lack of healthcare assistance as a result of structural violence against the poor. Unfortunately, this hospital is still struggling with the same problems and many other hospitals have the same reality where human lives are treated as lesser important than imaginary rules that make health case a commodity. "The way of Jesus" - that is what we saw in this paper presented in PSE and CSE - leads us to see that reality, to feel pain of the poor in our hearts, and to be distressed and restless until this reality of oppression continues to exist. Faith in Jesus leads us to live his way: joining the poor and struggling with them for liberation and justice.

\section{Bibliographic references}

BIEHL, João; PETRYNA, Adriana (Orgs.). When people come first: critical studies in global health. Princeton: Princeton University Press, 2013.

CAHILL, Lisa S. Theological bioethics: participation, justice and change. Washington, D.C.: Georgetown University Press, 2005.

CONE, James C. The cross and the lynching tree. Maryknoll, NY: Orbis Books, 2011.

CONFERÊNCIA EPISCOPAL LATINO AMERICANA. Documentos dos Celam: Rio de Janeiro, Medellín, Puebla e Santo Domingo. São Paulo: Paulus, 2005.

CRAIG, David M. Health Care as a Social Good: Religious Values and American Democracy. Washington, D.C.: Georgetown University Press, 2014.

DANIEL, Norman. Just Health: meeting health needs fairly. New York: Cambridge University Press, 2008. 
DORRIEN, Gary. Social ethics in the making: interpreting an American tradition. Chichester, UK / Malden, MA: Wiley-Blackwell, 2011.

FRANCIS, Pope. "Apostolic Exhortation Evangelii Gaudium". Retrieved from: $<$ http://www.vatican.va/holy_father/francesco/apost_exhortations/ documents/papa-francesco_esortazione-ap_20131124_evangeliigaudium_en.html>. 31 / December / 2016.

FARMER, Paul. Pathologies of power: health, human rights, and the new war on the poor. Berkeley: University of California Press, 2003.

FARMER, Paul. "Reimagining accompaniment: a doctor's tribute to Gustavo Gutiérrez". In: GRIFFIN, Micahel; BLOCK, Jennie Weiss (Orgs.). In the company of the poor: conversations with Dr. Paul Farmer and Fr. Gustavo Gutiérrez. Maryknoll, NY: Orbis Books, 2013, pp. 15-26.

Global Burden Disease Study 2015 - Sustainable Development Goals Collaborators. "Measuring the health-related Sustainable Development Goals in 188 countries: a baseline analysis from the Global Burden of Disease Study 2015". The Lancet 338 (2016), pp. 1813-1850. Retrieved from: <http://dx.doi.org/10.1016/S0140-6736(16)31467-2>. 31 / December / 2016.

GUTIERREZ, Gustavo. Teologia da libertação. 4. ed. Petrópolis, RJ: Vozes, 1983.

HAUERWAS, Stanley. The peaceable kingdom: a primer in Christian ethics. Notre Dame: University of Notre Dame Press, 1991.

HAUERWAS, Stanley. "God, Medicine, and the Problems of Evil". Reformed Journal 38 (1988), pp. 16-22.

HAUERWAS, Stanley. "Abortion and narrative ethics: A critical appraisal of Callahan and Grisez”. Cross Currents 21 (1971), pp. 399-414.

HAUERWAS, S.; BONDI, R. "Memory, community and the reasons for living: theological and ethical reflections on suicide and euthanasia". Journal of the American Academy of Religion 44 (1976), pp. 439-452.

LONG, D. Stephen. Christian ethics: a very short introduction. New York: Oxford University Press, 2010.

LONG, D. Stephen. "Moral theology". In: WEBSTER, John (Org.). Oxford handbook of systematic theology. Oxford, NY: Oxford University Press, 2006. 
KEENAN, James F. A history of catholic moral theology in the twentieth century: from confessing sins to liberating consciences. New York: Continuum, 2010.

MASSINGALE, Bryan N. Racial Justice and the Catholic Church. Maryknoll, NY: Orbis Books, 2010.

NIEBUHR, Reinhold. An interpretation of Christian ethics. Louisville, KY: Westminster John-Knox Press, 2013.

O'BRIEN, D. J.; SHANNON T. A. (Orgs.). Catholic social thought: the documentary heritage. Maryknoll, NY: Orbis Books, 2010.

PONTIFICAL COUNCIL FOR JUSTICE AND PEACE. Compendium of the social doctrine of the church. Washington, D.C.: Libreria Editrice Vaticana, 2004.

RAUSCHENBUSCH, Walter. A theology for the social gospel. Louisville, KY: Westminster John-Knox Press, 1997.

SEN, Amartya. Development as freedom. New York: Anchor Books, 2000.

YODER, John Howard. The politics of Jesus. Grand Rapids: Eerdmans, 1991.

VIDAL, Marciano. "Gaudium et spes y teología moral: A los 50 anos del Concilio Vaticano II”. Moralia 35 (2012), pp. 102-133.

Alexandre Andrade Martins, MI

Doutor em Ética Teológica/Bioética pela Marquette University Arthur J. Schmitt Fellow e Professor Adjunto na Marquette University Milwaukee / WI - United States E-mail: alexandre.martins@marquette.edu

Recebido em: 03/01/2017

Aprovado em: 20/03/2017 